\title{
Review \\ Echocardiography in Pulmonary Arterial Hypertension: Is It Time to Reconsider Its Prognostic Utility?
}

\author{
Ioannis T. Farmakis ${ }^{1,+}$, Eftychia Demerouti ${ }^{2, *}+{ }^{+} \mathbb{D}$, Panagiotis Karyofyllis ${ }^{3}$, George Karatasakis ${ }^{2}$, \\ Maria Stratinaki 4 (D), Dimitrios Tsiapras ${ }^{2}$, George Athanassopoulos ${ }^{2}$, Vassilios Voudris ${ }^{3}$ \\ and George Giannakoulas ${ }^{1} \mathbb{D}$
}

1 Cardiology Department, AHEPA University Hospital, Aristotle University of Thessaloniki, PC 54621 Thessaloniki, Greece; itfarmakis@gmail.com (I.T.F.); g.giannakoulas@gmail.com (G.G.)

2 Non-Invasive Cardiology Department, Onassis Cardiac Surgery Center, PC 17674 Athens, Greece; georgekar2001@yahoo.com (G.K.); dtsiapras@hotmail.com (D.T.); gapostol@otenet.gr (G.A.)

3 Invasive-Cardiology Department, Onassis Cardiac Surgery Center, PC 17674 Athens, Greece; pakar768@yahoo.gr (P.K.); vvoudris@otenet.gr (V.V.)

4 Department of Cardiology, General Hospital Venizeleio, PC 71409 Irákleion, Greece; maria.stratinaki@gmail.com

* Correspondence: efidemer@otenet.gr; Tel.: +30-2109493000

+ The authors contributed equally to the article.

\section{check for} updates

Citation: Farmakis, I.T.; Demerouti, E.; Karyofyllis, P.; Karatasakis, G.; Stratinaki, M.; Tsiapras, D.; Athanassopoulos, G.; Voudris, V.; Giannakoulas, G. Echocardiography in Pulmonary Arterial Hypertension: Is It Time to Reconsider Its Prognostic Utility? J. Clin. Med. 2021, 10, 2826. https://doi.org/10.3390/jcm10132826

Academic Editor: Andrea Igoren Guaricci

Received: 5 June 2021

Accepted: 24 June 2021

Published: 26 June 2021

Publisher's Note: MDPI stays neutral with regard to jurisdictional claims in published maps and institutional affiliations.

Copyright: (c) 2021 by the authors. Licensee MDPI, Basel, Switzerland. This article is an open access article distributed under the terms and conditions of the Creative Commons Attribution (CC BY) license (https:// creativecommons.org/licenses/by/ $4.0 /)$.

\begin{abstract}
Pulmonary arterial hypertension (PAH) is characterized by an insult in the pulmonary vasculature, with subsequent right ventricular $(\mathrm{RV})$ adaptation to the increased afterload that ultimately leads to RV failure. The awareness of the importance of RV function in PAH has increased considerably because right heart failure is the predominant cause of death in PAH patients. Given its wide availability and reduced cost, echocardiography is of paramount importance in the evaluation of the right heart in PAH. Several echocardiographic parameters have been shown to have prognostic implications in PAH; however, the role of echocardiography in the risk assessment of the PAH patient is limited under the current guidelines. This review discusses the echocardiographic evaluation of the RV in PAH and during therapy, and its prognostic implications, as well as the potential significant role of repeated echocardiographic assessment in the follow-up of patients with PAH.
\end{abstract}

Keywords: echocardiography; pulmonary arterial hypertension; right ventricle

\section{Introduction}

Pulmonary arterial hypertension (PAH) is characterized by progressive proliferation and remodeling in the pulmonary vascular bed. The insult of the pulmonary vasculature leads to an increase in pulmonary vascular resistance (PVR), with subsequent adaptation of the right ventricle to the increased afterload [1]. Ultimately, the exhaustion of compensatory mechanisms results in right ventricular (RV) dysfunction and right heart failure (RHF) - the leading cause of death for PAH patients.

The awareness of the importance of RV function in PAH has increased considerably, as it determines the functional status, exercise capacity, and outcome of patients. Non-invasive imaging techniques - such as echocardiography and cardiac magnetic resonance (CMR)are of paramount importance in the evaluation of the right heart. Given its wide availability and low cost, echocardiography is appealing to both PAH patients and their attending physicians. According to the latest ESC/ERS Guidelines, the utility of echocardiography has been sized down to two echocardiographic parameters - the right atrium end-systolic area, and the presence of pericardial effusion-which have been incorporated in the routine risk assessment of the PAH patient [2]. However, many echocardiographic indices have been reported to have prognostic implications, and are increasingly incorporated into clinical practice; however, it is not yet clearly elucidated which exact echocardiographic parameters are imperative in the assessment of RV maladaptation and failure and, therefore, 
specific recommendations do not exist. This raises the interesting question of which aspects of RV function evaluated by echocardiography should be routinely used as parameters in PAH patients' risk assessment at baseline assessment and during follow-up.

This review will discuss the pathophysiological response of the RV in PAH, as well as the prognostic implications of its dysfunction, the echocardiographic evaluation of the RV in PAH at baseline and after targeted therapy-and its prognostic implications-and, lastly, the potential significant role of repeated echocardiographic assessment in comparison with right heart catheterization (RHC) in the follow-up of patients with PAH.

\section{Right Ventricular Function in PAH}

\subsection{Pathophysiology of Right Ventricular Adaptation and Right Heart Failure}

PAH represents a progressive disorder affecting the whole cardiopulmonary unit, consisting of the right ventricle and the pulmonary vasculature [3]. These two main functional subsystems have unique intrinsic characteristics. On the one hand, load-independent intrinsic characteristics-such as ventricular contractility and diastolic stiffness-delineate the ventricular component, while, on the other hand, vascular resistance and compliance are load-dependent and describe the pulmonary vascular system [4]. The interaction between the two results in system parameters, which describe global function (ventricular and load), and these are represented mainly by (a) the ejection fraction (EF) and cardiac output $(\mathrm{CO})$, and (b) the pulmonary pressure, respectively $[1,4]$. The term "ventriculoarterial coupling" describes the adaptation of the RV to the increased pulmonary vascular load, and is used as a measure of the efficiency of energy transfer from the right ventricle to the arterial vessels, while it has additional prognostic significance [5]. The gold standard measure for describing ventriculoarterial coupling is the $\mathrm{E}_{\mathrm{es}} / \mathrm{E}_{\mathrm{a}}$ ratio, where $\mathrm{E}_{\mathrm{es}}$ indicates the end-systolic elastance-an intrinsic measure of RV contractility-while $\mathrm{E}_{\mathrm{a}}$ indicates the arterial elastance, a measure of total load in the pulmonary vasculature. Both indices are estimated invasively from the pressure-volume loop [6].

The RV adaptation is a spectrum ranging from well-adapted to maladapted RV function, and progresses in relation to the increased vascular load [7]. At initial stages, the ventriculoarterial coupling is minimally altered through an adaptive remodeling, which encompasses cardiac muscle hypertrophy, resulting in a normal or mildly decreased RV function, and a preserved or mildly depressed exercise capacity and ventilatory efficiency. However, the increasingly growing pressure load leads to a halt of the hypertrophic process and reduced right cardiac function. In order to maintain the cardiac output, the heart rate increases and ventricular dilation occurs, which leads to greater oxygen consumption with less efficiency, increased RV wall stress and stiffness, and deleterious impact on the left ventricular function. Indirect left ventricular (LV) dysfunction is present in the late stages of disease, through ventricular interdependency [8]. The impaired filling of the LV owing to the leftward septal bowing and the reduced stroke volume (SV) of the right ventricle causees atrophic remodeling of the LV $[9,10]$. The atrophic LV has decreased contractile power, owing to the reduced cross-sectional area of the LV cardiomyocytes [11]. Experimental data have shown reverse of the LV atrophy with alleviation of the RV pressure overload, and clinical studies indicate partially restored LV function with improved hemodynamics, owing possibly to the resynchronization of the RV and LV [12-14].

Consequently, the maladaptive remodeling of the RV results in "uncoupling", which is characterized by moderate or severe RV dilation, with subsequent systolic dysfunction [15]. As the disease progresses, the compensatory mechanisms are progressively exhausted, leading to uncoupling and, ultimately, to RHF, which represents a clinical syndrome that includes decreased RV function, leading to insufficient cardiac output and elevated filling pressures.

\subsection{Prognostic Significance of Right Ventricular Function in PAH}

RHF is the predominant cause of death in PAH patients [4]. This has been a consistent finding among large cohorts, but also smaller studies, where the survival of PAH patients 
is strongly related to the avoidance of RHF. Several registries underline the utility of right heart and pulmonary hemodynamics for survival prediction [16-19]. A common characteristic of the risk prediction models of survival in PAH is that they do not incorporate the crucial transition from RV adaptation to RV maladaptation and, subsequently, to RV failure. However, this transition is progressive, and the definition of RV maladaptation is elusive. There is ample evidence that the RV end-diastolic volume (RV EDV), the end-systolic volume (ESV), the SV, and the right ventricular ejection fraction (RVEF) - as defined by SV/EDV—contain the foremost prognostic information. In case of an adapted $\mathrm{RV}$, increased afterload leads to hypertrophy and increased contractility, with preserved or mildly increased RV dimensions and preserved SV, whereas in maladaptation the RV volumes increase and the SV decreases.

Several studies have showcased the usefulness of the CMR-measured RVEF, with values $<35 \%$ being consistently prognostic of decreased survival $[5,15,20]$. Moreover, Vanderpool et al. showed the prognostic relevance of ventriculoarterial decoupling in 50 patients with PAH [5]. A subsequent study by Brewis et al. was able to confirm that the SV /ESV ratio predicted survival [15]. Interestingly, the SV/ESV and the RVEF share a non-linear relationship, and SV/ESV may be a better predictor of outcomes than RVEF [21]. In addition, other CMR studies have demonstrated the predictive value of RVEF, EDV index, ESV index, and RV mass index [22].

Ventricular interdependency and the subsequent LV dysfunction also have prognostic implications [23]. Indeed, LV systolic strain is reduced in subjects with PAH, and is independently associated with mortality, despite the preservation of LVEF [24-26]. Furthermore, the LV peak filling rate is altered in proportion to the decreased RVEF, denoting diastolic dysfunction of the LV in progressed PH [27]. Metrics of diastolic dysfunction-such as the peak early diastolic velocity and abnormal $\mathrm{E}$ wave velocities, as assessed by CMR tissue phase mapping - have been associated with decreased survival [28,29].

\section{Echocardiographic Evaluation of Right Ventricular Function and Its Prognostic Relevance in PAH}

The American Society of Echocardiography Guidelines offer a comprehensive review of right heart evaluation $[30,31]$. Estimation of RV contractility by echocardiography is a challenging task due to its unique anatomy; however, many indices have been described as parameters of RV global function. In everyday clinical practice, the most commonly used indices in PAH patients are: RV dimensions, tricuspid annular plane systolic excursion (TAPSE), RV fractional area change (FAC), eccentricity index, RV myocardial performance index (MPI), tissue Doppler imaging (TDI)-derived tricuspid lateral annular systolic velocity (RV S'), right atrial end-systolic size, and pericardial effusion [32-36].

TAPSE is mostly regarded as a surrogate for RV systolic function. It was found to predict survival in 63 patients with $\mathrm{PAH}$ [37], but failed to predict mortality in a subsequent study of 777 patients with precapillary $\mathrm{PH}$-and especially those in New York Heart Association functional class III-IV with RV dilation [38]. Although TAPSE is easy to measure and reproducible, it predominantly mirrors longitudinal RV function, is volumeand load-dependent, and is not accurate in patients with regional RV wall abnormalities and significant secondary tricuspid regurgitation [39]. RV FAC reflects both longitudinal and radial components of RV contraction, correlates well with RVEF via MRI, and has been shown to predict survival in patients with PAH $[38,40]$; however, it neglects the contribution of the RV outflow tract to overall systolic function, and has only fair interobserver reproducibility [31]. The eccentricity index is acquired from the short-axis view of the $\mathrm{LV}$. In severe $\mathrm{PH}$ and increased RV pressures, the interventricular septum shifts towards the left side, giving the LV its characteristic D-shape, and has been shown to add to the prognostic stratification of patients with PAH [34]. RV MPI, also known as the Tei index, incorporates systolic and diastolic time intervals to reflect global RV function [41], with values of $\geq 0.64$ [38] and $>0.88$ [42] reported to predict survival; however, it requires the acquisition of images in two different cardiac cycles, making it difficult to obtain, and also has not been shown to have a strong correlation with CMR-derived RVEF-as opposed 
to TAPSE [43]. TDI RV S' is a reliable and reproducible technique, with the advantage of being validated by a large, population-based study [44]. Values of $S^{\prime}<10 \mathrm{~cm} / \mathrm{s}$ raise the suspicion for abnormal RV function. Moreover, the isovolumetric peak velocity at the tricuspid annulus - which can be assessed by DTI-is an independent predictor of overall survival in patients with severe PH [45]. RA size and pericardial effusion use in PAH are discussed later in this review.

The TAPSE/pulmonary arterial systolic pressure (PASP) ratio seems to represent a significant marker of ventriculoarterial coupling. In patients with left heart failure, the TAPSE/PASP ratio, when combined with exercise ventilation, was a strong predictor of major cardiac events [46]. Tello et al. showed that the TAPSE/PASP ratio also has prognostic relevance in patients with $\mathrm{PAH}$, and is independently associated with overall mortality, even after adjusting for other echocardiographic or hemodynamic prognostic indicators [47]. The TAPSE/PASP ratio was also validated as a surrogate of invasively measured ventriculoarterial coupling in severe PH [48]. In recent years, several other echocardiographic indices of RV function have been proposed to reflect ventriculoarterial coupling in PH patients, including the ratio of RVFAC to mean PAP (measured by right heart catheterization) [49], the ratio of RV area change to RV end-systolic area [50], the ratio of $S^{\prime} / R V$ to end-systolic area index [51], and the ratio of TAPSE to pulmonary artery acceleration time [52]. However, none of these proposed echocardiographic surrogates, with the exception of the TAPSE/PASP ratio, have been directly compared with pressurevolume loop measures of ventriculoarterial coupling. Therefore, the TAPSE/PASP ratio is a straightforward, promising echocardiographic parameter derived from routinely measured indices, fully applicable on the daily basis routine.

In addition to the traditional and well-established direct and indirect measures of $\mathrm{RV}$ function, a number of novel unconventional echocardiographic techniques have been introduced in the recent years. Two-dimensional (2D) speckle tracking echocardiography (STE)-derived RV strain is a measure of myocardial deformation, and is useful in the evaluation of the function of the right heart, as it is independent of endocardial border tracings and geometric assumptions [53]. The systolic function of the RV relies heavily on its longitudinal contraction, acting more or less like a piston pump; thus, the longitudinal strain - rather than the circumferential or radial strain-is the preferable parameter to measure [54]. RV longitudinal systolic strain (RV LSS) is a very useful marker of subclinical deterioration, even before conventional measures—-such as the TAPSE-deteriorate. Notably, pressure overload in PAH results in the hypertrophy of the RV and, therefore, strain acquisition in the normally thin-walled RV is easier in the PAH patient than in the normal RV. In chronic PH, 2D-STE and 3D-STE parameters perform better than other conventional echo indices, such as the TAPSE and FAC, in recognizing global and regional RV dysfunction, which is associated with hemodynamic signs of RV failure [55]. Studies indicate that the RV LSS correlates well with markers of functional assessment, and is a powerful predictor of survival in PAH [56,57]. Moreover, a recent meta-analysis confirmed that the global RV LSS measured using 3D and 2D echocardiography has potential as a predictor of survival in patients with PH [58]. Recently, RV-strain-derived post-systolic patterns that reflect the RV diastolic function have been identified to be clinically meaningful and increase the prognostic power for clinical worsening [59].

Regional heterogeneity of RV function can be echocardiographically evaluated by RV dyssynchrony, which is measured using 2D-STE, and is defined as the R-R-corrected standard deviation of the times to peak systolic strain for the four mid-basal RV segments [60]. $\mathrm{RV}$ dyssynchrony has been found to be impaired even in mild/borderline PH, and may reflect early ventriculoarterial uncoupling [61]. The addition of RV dyssynchrony to multivariate models improves prediction of clinical worsening and decline in exercise capacity, even adjusting for conventional clinical, echo, and hemodynamic parameters $[62,63]$.

Moreover, real-time 3D echocardiography is a promising tool to quantitate right heart chamber volumes and estimate RV function, because it captures the complex RV morphology, and compares fairly well with CMR, while normal reference values are available [64-66]. 
Studies implementing 3D echocardiography have shown adverse remodeling of the RV and the tricuspid valve in $\mathrm{PH}$, which is linked to an adverse clinical outcome [67-69]. Furthermore, a 3D echocardiographic estimated RVEF has been shown to predict outcomes in $\mathrm{PH}$ [70]. 3D echocardiography techniques could be deployed in the future to produce less invasive pressure-volume analyses in order to accurately evaluate RV function [71]. However, to date, these novel methods have not been widely implemented in routine practice, as there are drawbacks - mainly related to the quality of the image acquisition; they are heavily dependent on the anatomy of the RV-the greater the diameter of the $\mathrm{RV}$, the less reliable is 3D echocardiography's capacity to calculate volumes. Thus, these indices are not always easy to obtain in all PAH patients, and are mainly used in selected patients and in expert centers for research purposes.

\section{Echocardiography in PAH}

\subsection{The Use of Echocardiography for Risk Stratification in PAH}

According to proceedings from the 6th World Symposium on PH in 2019, PAH patients should be stratified as low, intermediate, or high risk for annual mortality, at baseline assessment and during their routine follow-up every 3-6 months [72]. Several risk assessment scores have been employed in recent years [73]; among these, the ESC/ERS stratification score has been a posteriori validated by three retrospective studies, and includes clinical, imaging, laboratory, cardiopulmonary exercise testing, and hemodynamic parameters [74-76]. The United States Registry to Evaluate Early and Long-Term PAH Disease Management (REVEAL) score is prospectively validated, and includes multimodal parameters $[18,77]$. Both scores' common goal is to direct PAH therapy and drive patients into the low-risk zone of the disease.

Of echocardiographic parameters, only the presence of pericardial effusion and the RA size are quoted for risk stratification in the aforementioned scores and current guidelines. Truly, pericardial effusion is one of the most reported prognostic parameters associated with mortality in PAH. Pericardial effusion in PAH is driven by increased right atrial pressure, which impairs the venous and lymphatic drainage of the myocardium and is, therefore, a reflection of RV diastolic dysfunction [78,79]. Pericardial effusion was reported in $54 \%$ of patients with severe IPAH, with larger effusions being associated with hemodynamic and echocardiographic evidence of right heart failure, impaired exercise tolerance, and poor prognosis at the one-year follow-up [80]. However, pericardial effusion presents late in the course of the disease- a finding which may necessitate immediate treatment with intravenous epoprostenol, as these patients present high annual mortality rates. Thus, pericardial effusion is not a frequent finding during a close patient's follow-up, and certainly is not useful for a more refined monitoring of right ventricular function. Moreover, in certain entities-such as connective tissue diseases-pericardial effusion may reflect the serous involvement of the pericardium rather than the severity of the pulmonary vascular disease.

RA size, as an indirect measure of RV function, has also proven to be relevant to the prognosis, and in a recent meta-analysis the risk of all-cause mortality increased by $50 \%$ for every 5-unit increase in RA area [81]. In addition, metrics of RA function-such as the RA function index (RAFi) and the RA peak longitudinal strain — have been shown to strongly predict clinical failure in precapillary $\mathrm{PH}[82,83]$.

Although we have mentioned several other echocardiographic parameters that assess the global function of the right ventricle, and that may have prognostic relevance, it is interesting that none of them is mentioned in the current guidelines. The problem lies in the fact that the majority of these echo indices has been prognostically evaluated only by small, single-center studies, and there has not been any systemic evaluation of the RV function along with the other parameters of clinical scores. A large prospective cohort study that will simultaneously assess a wide range of echocardiographic, but also clinical, laboratory, and hemodynamic indices, is needed in order to better incorporate echocardiography in PAH risk stratification [84]. 


\subsection{Effects of PAH-Targeted Drug Therapy on the Right Ventricular Function}

Management of PAH has substantially improved in the last decade, and this has clear effects on long-term efficacy measures $[85,86]$. Phosphodiesterase type V inhibitors (sildenafil and tadalafil) and endothelin receptor antagonists (ambrisentan, bosentan, and macitentan) form the forefront of therapy in $\mathrm{PAH}$, with increasing rates of upfront double combination therapy, while parenteral prostanoids are reserved for high-risk patients. Breakthroughs in PAH treatment in the recent years include the approval of the soluble guanylyl cyclase (sGC) stimulator riociguat and the oral prostacyclin receptor agonist selexipag. It is becoming increasingly apparent that by targeting multiple pathological pathways using combination therapy, we ensure the best outcome for our patients, as this strategy improves pulmonary hemodynamics, functional class, and cardiac functional parameters [87].

However, the direct effects of PAH-targeted therapy on the RV have not yet been sufficiently investigated. The Euro MR Study, based on MRI-which looked at patients from Glasgow (UK), Rome (Italy), Graz (Austria), and Amsterdam (the Netherlands) before and after 4 and 12 months-showed that the RV systolic and diastolic volumes as well as the SV improved after the initiation of PAH-specific therapy [88]. Few studies are published with data on RV function estimated by echocardiography in relation to PAH-targeted therapy. Table 1 presents human studies with PAH-targeted therapy and their effect on RV function based on echocardiographic parameters [78,89-111]. Both monotherapy and especially combination therapy significantly improve RA size, RV size, diastolic eccentricity index, MPI and TAPSE, RV strain, and RV strain rate, and cause greater alterations of the $\mathrm{RV}$ end-diastolic area and systolic and diastolic eccentricity index [37,112-116]. Up-front triple combination therapy in severe non-reversible $\mathrm{PAH}$ was associated with right heart remodeling and considerable improvement in RHC parameters [89].

Table 1. Human studies with PAH-targeted therapy and their effect on RV function based on echocardiographic parameters.

\begin{tabular}{|c|c|c|c|c|}
\hline Authors & $\mathrm{N}$ of Patients & Treatment (Duration) & $\begin{array}{l}\text { Effect on ECHO } \\
\text { Parameters }\end{array}$ & $\begin{array}{l}\text { Effect on Other } \\
\text { Parameters }\end{array}$ \\
\hline D'Alto et al. [89] [2020) & 21 & $\begin{array}{c}\text { Ambrisentan }+ \\
\text { Tadalafil + Treprostinil } \\
\text { (2 years) }\end{array}$ & $\begin{array}{c}\downarrow \text { RAA } \\
\downarrow \text { RVA } \\
\downarrow \text { LV EI } \\
\uparrow \text { RVFAC }\end{array}$ & $\begin{array}{c}\uparrow 6 \mathrm{MWD} \\
\downarrow \mathrm{RAP} \\
\downarrow \mathrm{mPAP} \\
\downarrow \mathrm{PVR} \\
\downarrow \text { NT-proBNP } \\
\uparrow \mathrm{CI}\end{array}$ \\
\hline Saggar et al. (2013) [90] & 15 & Treprostinil (12 weeks) & $\begin{array}{c}\downarrow \text { RVEDA } \\
\downarrow \text { LV EI } \\
\uparrow \text { TAPSE }\end{array}$ & $\begin{array}{c}\uparrow 6 \mathrm{MWD} \\
\downarrow \mathrm{RAP} \\
\downarrow \mathrm{mPAP} \\
\uparrow \mathrm{CI} \\
\downarrow \mathrm{PVR} \\
\downarrow \mathrm{TPG} \\
\downarrow \text { SVi } \\
\downarrow \mathrm{BNP}\end{array}$ \\
\hline Mercurio et al. (2017) [91] & $\begin{array}{c}23 \\
\text { (Scleroderma patients) }\end{array}$ & $\begin{array}{l}\text { Tadalafil + } \\
\text { Ambrisentan } \\
\text { (36 weeks) }\end{array}$ & $\begin{array}{c}\downarrow \text { RAA } \\
\downarrow \text { RVA } \\
\downarrow \text { RV FWT } \\
\uparrow \text { RVFAC } \\
\uparrow \text { TAPSE } \\
\downarrow \text { RVSP } \\
\downarrow \text { RVLSS }\end{array}$ & \\
\hline
\end{tabular}


Table 1. Cont.

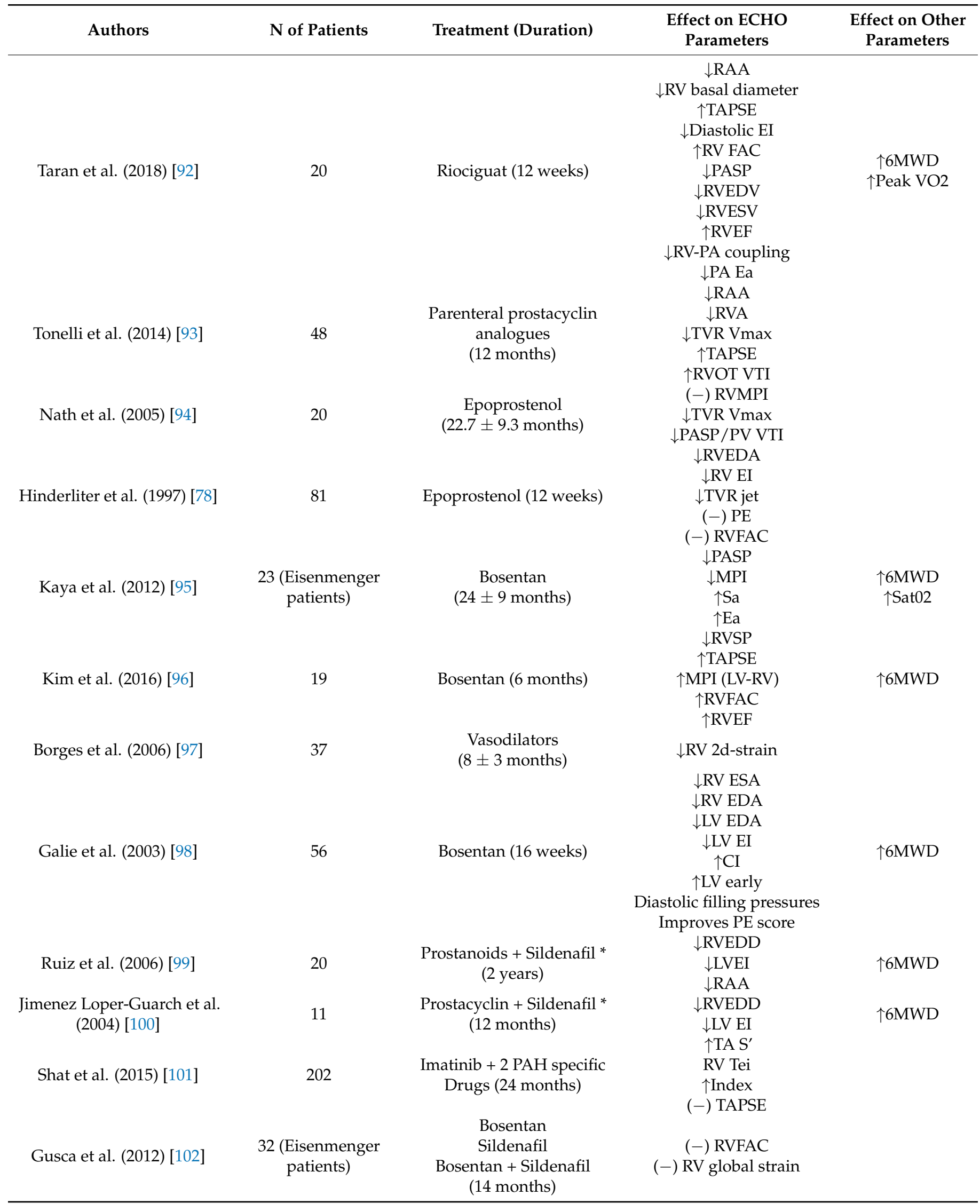


Table 1. Cont.

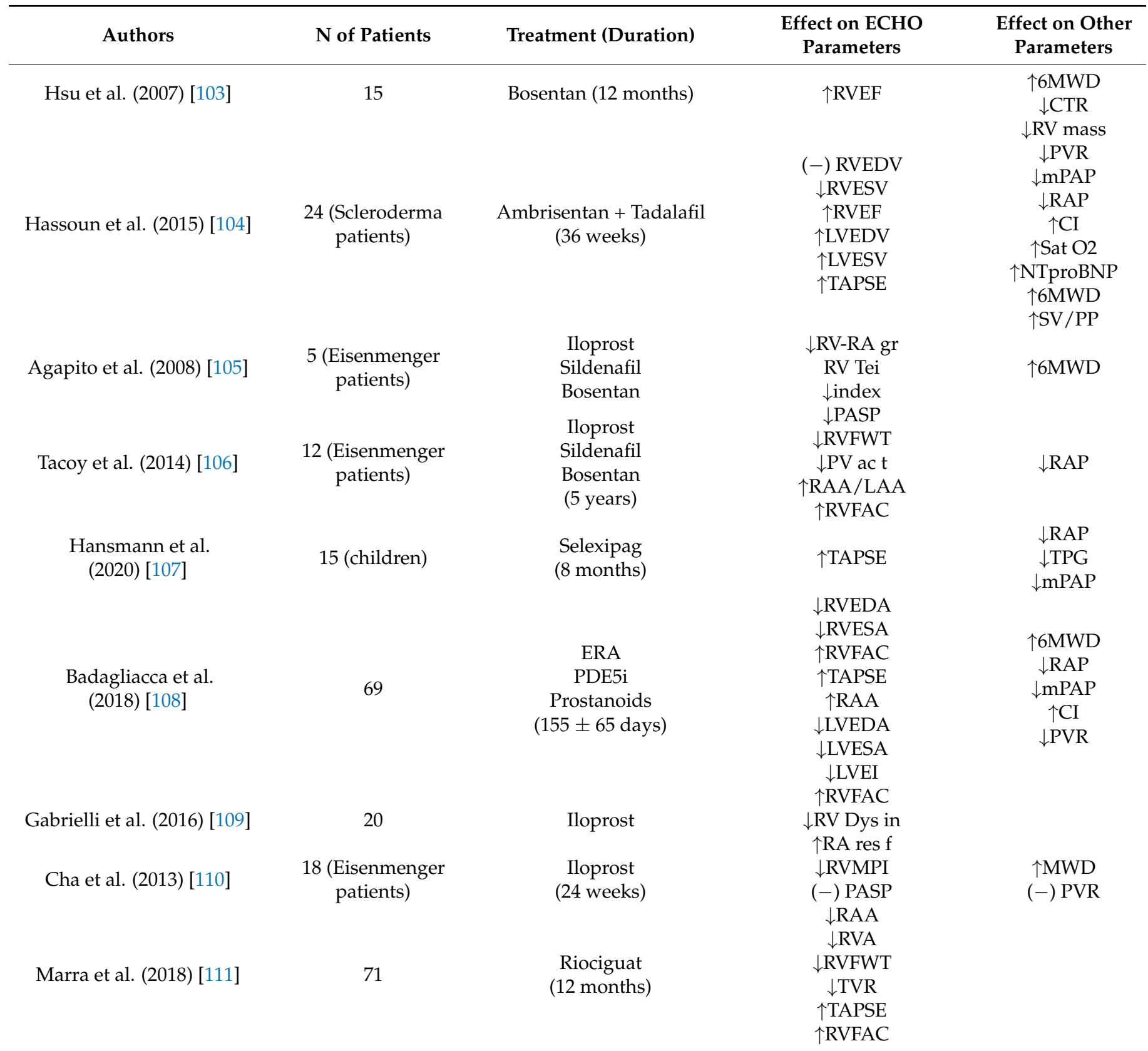

RAA: right atrium area; RVA: right ventricle area; LV EI: left ventricle eccentricity index; RVFAC: right ventricle fractional area; RVEDA: right ventricle end-diastolic area; TAPSE: tricuspid annular plane systolic excursion; RVFWT: right ventricle free-wall thickness; RVSP: right ventricle systolic pressure; RVLSS: right ventricle longitudinal systolic strain; EI: eccentricity index; PASP: pulmonary artery systolic pressure; RVEDV: right ventricle end-diastolic volume; RVESV: right ventricle end-systolic volume; RVEF right ventricle ejection fraction; RV: right ventricle; PA: pulmonary artery; TVR: tricuspid valve regurgitation; Vmax: maximal velocity; RVOT VTI: right ventricle outflow tract velocity time integral; RVMPI: right ventricle myocardial performance index; PVVTI: pulmonary valve velocity time integral; PE: pericardial effusion; Sa: systolic myocardial velocity; Ea: early diastolic myocardial relaxation velocity; RVESA: right ventricle end-systolic area; LVEDA: left ventricle end-diastolic area; LVESA: left ventricle end-systolic area; CI: cardiac index; RVEDD: right ventricle end-diastolic diameter; TA S': tricuspid annular peak systolic velocity; LVEDV: left ventricle end-diastolic volume; LVESV: left ventricle end-systolic volume; RV Dys in: right ventricle dyssynchrony index; RA res f: right atrium reservoir function (speckle tracking); 6MWD: 6-min walking distance; RAP: right atrial pressure; mPAP: mean pulmonary artery pressure; PVR: pulmonary vasculature resistance; TPG: transpulmonary gradient; SVi: stroke volume index; Sat: saturation; SV: stroke volume; PP: pulmonary artery pulse pressure; $(-)$ : no effect. ${ }^{*}$ Effect of added sildenafil. 


\section{Follow-Up in PAH: Repeated Assessment with RHC or Echocardiography?}

There is a debate in the literature, and between experts, whether it is truly essential to perform serial RHCs for PAH patients' follow-up, or whether non-invasive methods could provide accurate prognostic evaluation. RHC is an invasive procedure, not always available in all hospitals, and may infrequently lead to several complications-especially when performed by non-experts. On the other hand, echocardiography is a non-invasive procedure, with no potential harm, feasible in everyday clinical practice, and with less cost. Routine invasive follow-up may not be necessary in patients with low-risk non-invasive criteria [76,117]. Moreover, progressive RV dysfunction may not be accompanied by hemodynamic changes, such as in PVR. In a cohort of 110 patients, Van der Veerdonk et al. found that after the initiation of PAH-targeted therapy, RV function may deteriorate despite a reduction in PVR [20]. In this cohort, changes in PVR did not differ between survivors and non-survivors; however, during follow-up, survivors showed increased RVEF, whereas non-survivors showed decreased RVEF, suggesting that loss of RV function is associated with a poor outcome, irrespective of any changes in PVR. Another important finding is that signs of RV deterioration can be seen in PAH patients with no evidence of clinical deterioration. Van der Veerdonk et al. included 22 stable idiopathic PAH patients (as reflected by stable or improving New York Heart Association functional class II-III and exercise capacity) and performed a 5-year follow-up. RV volumes and RVEF seemed to deteriorate in some stable patients, and changes in these parameters could precede disease progression and mortality [118].

The additive benefit of RV function-as assessed by echocardiography, on top of wellestablished risk prediction models-is not thoroughly studied. Haddad et al. constructed a right heart score- which incorporated RV systolic function grade, severe RA enlargement, and systemic blood pressure $<110 \mathrm{mmHg}$ - and this compared favorably with the NIH survival equation, and did not differ from the REVEAL score, while it was also the only predictor of outcome in the validation cohort [119]. In addition, the RV end-systolic remodeling index (defined by the ratio of the lateral RV wall length to the septal height) was incremental to predictive risk models, including the REVEAL score [120]. The RV free wall LSS and the right atrial peak longitudinal strain have also been shown to have an additive prognostic value and improve risk stratification in incident, naïve to PAH-targeted therapies [121]. Recently, Ghio et al. have evaluated an echocardiographic approach based on multiple parameters (TAPSE, tricuspid regurgitation, and inferior vena cava diameter) to separate $\mathrm{PAH}$ patients into three groups that represent progressive degrees of RV impairment [122]. They showed that this approach is effective in stratifying the probability of survival in the PAH population, while the inclusion of RA area and pericardial effusion did not add prognostic value to this approach. Lastly, Zhao et al. demonstrated that the echocardiographically measured attenuated right heart remodeling — as defined by the presence of decreased RA area, RV mid-diameter, and LV end-diastolic eccentricity index - was independently associated with mortality, and also increased the diagnostic ability of the French non-invasive risk assessment criteria [123].

\section{Conclusions}

The awareness of the importance of the RV in PAH has increased considerably. Hypothetically, if normal RV function were the only goal during the follow-up of PAH patients, their survival would be better. Today, non-invasive imaging is increasingly being used for the study of RV and pulmonary circulation, with increased focus on functional relevance. Echocardiography is a widely accessible, non-invasive method, and provides a global assessment of RV function. An important question is how best to incorporate the accumulating data on echocardiographic parameters for the prognostic significance of $\mathrm{PAH}$ into investigation and clinical practice. According to the published data, it seems that TAPSE, RA area, RVFAC, eccentricity index, and RVLSS could be the echocardiographic parameters that we can use in our daily practice, to evaluate the RV function in PAH patients at baseline, and during their follow-up after specific drug therapy (Figure 1). 


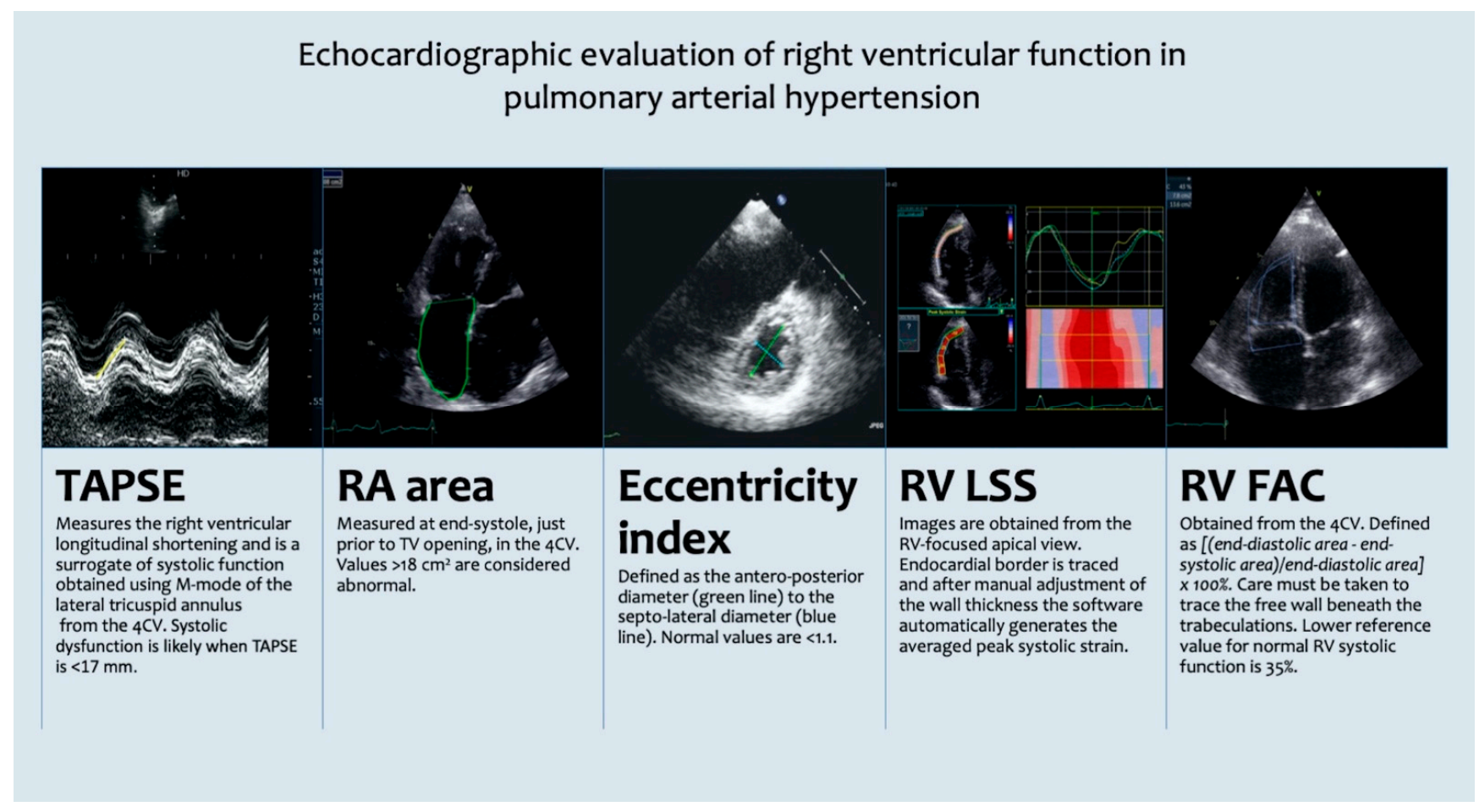

Figure 1. Echocardiographic evaluation of right ventricular function in pulmonary arterial hypertension. 4CV: four-chamber view; FAC: fractional area change; LSS: longitudinal free-wall strain; RA: right atrium; RV: right ventricular; TAPSE: tricuspid annular plane systolic excursion.

Further echocardiographic studies are needed to support these recommendations on the prognostic role of specific echocardiographic indices both at baseline, and especially during follow-up assessments, to evaluate the effect of PAH-targeted treatments on RV performance as measured by echocardiography. However, since echocardiography is not as reproducible or accurate as CMR, which seems to be the gold standard in the assessment of RV function, larger validation studies are needed in order to see which of those indices are most applicable to follow-up risk assessments. A large cohort outcome study comparing the afore-mentioned echocardiographic indices would also provide more answers as to whether the normalization of RV size and function as assessed by echocardiography predicts outcomes, either alone or in addition to multimodal parameters. Future trials of therapeutic interventions should incorporate echocardiographic indices as endpoints, and their association with clinical and hemodynamic parameters. Therefore, much work remains to take place identifying the most relevant indices for RV function and ventriculoarterial coupling estimation and their sensitivity to treatment strategies.

Funding: This research received no external funding.

Institutional Review Board Statement: Not applicable.

Informed Consent Statement: Not applicable.

Conflicts of Interest: The authors state that there is no conflict of interest regarding this work. Eftychia Demerouti declares consultancy and speaker fees from Actelion Pharmaceutical Hellas, Demo Hellas, GlaxoSmithkline, Janssen, Merck and Sharp and research support from Elpen Pharmaceuticals and Galenica. Panagiotis Karyofyllis declares consultancy fees from Actelion Pharmaceutical Hellas, Janssen and MSD Hellas. Dimitrios Tsiapras reports consultancy fees from GlaxoSmithkline. George Giannakoulas reports speaker and consultancy fees from Actelion, Bayer, ELPEN Pharmaceuticals, GSK, Pfizer, Lilly, and United Therapeutics, and research support from GSK, ELPEN Pharmaceuticals, and Galenica. 


\section{References}

1. Vonk-Noordegraaf, A.; Haddad, F.; Chin, K.M.; Forfia, P.R.; Kawut, S.M.; Lumens, J.; Naeije, R.; Newman, J.; Oudiz, R.J.; Provencher, S.; et al. Right Heart Adaptation to Pulmonary Arterial Hypertension: Physiology and Pathobiology. J. Am. Coll. Cardiol. 2013, 62, D22-D33. [CrossRef]

2. Galiè, N.; Humbert, M.; Vachiery, J.-L.; Gibbs, S.; Lang, I.; Torbicki, A.; Simonneau, G.; Peacock, A.; Vonk Noordegraaf, A.; Beghetti, M.; et al. 2015 ESC/ERS Guidelines for the diagnosis and treatment of pulmonary hypertension: The Joint Task Force for the Diagnosis and Treatment of Pulmonary Hypertension of the European Society of Cardiology (ESC) and the European Respiratory Society (ERS): Endorsed by: Association for European Paediatric and Congenital Cardiology (AEPC), International Society for Heart and Lung Transplantation (ISHLT). Eur. Heart J. 2016, 37, 67-119.

3. Champion, H.C.; Michelakis, E.D.; Hassoun, P.M. Comprehensive Invasive and Noninvasive Approach to the Right VentriclePulmonary Circulation Unit. Circulation 2009, 120, 992-1007. [CrossRef]

4. Vonk Noordegraaf, A.; Chin, K.M.; Haddad, F.; Hassoun, P.M.; Hemnes, A.R.; Hopkins, S.R.; Kawut, S.M.; Langleben, D.; Lumens, J.; Naeije, R. Pathophysiology of the right ventricle and of the pulmonary circulation in pulmonary hypertension: An update. Eur. Respir. J. 2019, 53, 1801900. [CrossRef]

5. Vanderpool, R.R.; Pinsky, M.R.; Naeije, R.; Deible, C.; Kosaraju, V.; Bunner, C.; Mathier, M.A.; Lacomis, J.; Champion, H.C.; Simon, M.A. RV-pulmonary arterial coupling predicts outcome in patients referred for pulmonary hypertension. Heart Br. Card. Soc. 2015, 101, 37-43. [CrossRef] [PubMed]

6. Tello, K.; Seeger, W.; Naeije, R.; Vanderpool, R.; Ghofrani, H.A.; Richter, M.; Tedford, R.J.; Bogaard, H.J. Right heart failure in pulmonary hypertension: Diagnosis and new perspectives on vascular and direct right ventricular treatment. Br. J. Pharmacol. 2021, 178, 90-107. [CrossRef] [PubMed]

7. Vonk Noordegraaf, A.; Westerhof, B.E.; Westerhof, N. The Relationship Between the Right Ventricle and its Load in Pulmonary Hypertension. J. Am. Coll. Cardiol. 2017, 69, 236-243. [CrossRef] [PubMed]

8. Gorter, T.M.; Willems, T.P.; van Melle, J.P. Ventricular interdependence in pulmonary arterial hypertension: Providing small pieces of a complex puzzle. Eur. J. Heart Fail. 2015, 17, 1-2. [CrossRef] [PubMed]

9. Hardziyenka, M.; Campian, M.E.; Reesink, H.J.; Surie, S.; Bouma, B.J.; Groenink, M.; Klemens, C.A.; Beekman, L.; Remme, C.A.; Bresser, P.; et al. Right ventricular failure following chronic pressure overload is associated with reduction in left ventricular mass: Evidence for atrophic remodeling. J. Am. Coll. Cardiol. 2011, 57, 921-928. [CrossRef]

10. Gan, C.T.-J.; Lankhaar, J.-W.; Marcus, J.T.; Westerhof, N.; Marques, K.M.; Bronzwaer, J.G.F.; Boonstra, A.; Postmus, P.E.; VonkNoordegraaf, A. Impaired left ventricular filling due to right-to-left ventricular interaction in patients with pulmonary arterial hypertension. Am. J. Physiol. Heart Circ. Physiol. 2006, 290, H1528-H1533.

11. Manders, E.; Bogaard, H.-J.; Handoko, M.L.; van de Veerdonk, M.C.; Keogh, A.; Westerhof, N.; Stienen, G.J.M.; dos Remedios, C.G.; Humbert, M.; Dorfmüller, P.; et al. Contractile Dysfunction of Left Ventricular Cardiomyocytes in Patients With Pulmonary Arterial Hypertension. J. Am. Coll. Cardiol. 2014, 64, 28-37. [CrossRef] [PubMed]

12. Han, J.-C.; Guild, S.-J.; Pham, T.; Nisbet, L.; Tran, K.; Taberner, A.J.; Loiselle, D.S. Left-Ventricular Energetics in Pulmonary Arterial Hypertension-Induced Right-Ventricular Hypertrophic Failure. Front. Physiol. 2018, 8. [CrossRef] [PubMed]

13. Roca, G.Q.; Campbell, P.; Claggett, B.; Vazir, A.; Quinn, D.; Solomon, S.D.; Shah, A.M. Impact of lowering pulmonary vascular resistance on right and left ventricular deformation in pulmonary arterial hypertension. Eur. J. Heart Fail. 2015, $17,63-73$. [CrossRef]

14. Mauritz, G.-J.; Vonk-Noordegraaf, A.; Kind, T.; Surie, S.; Kloek, J.J.; Bresser, P.; Saouti, N.; Bosboom, J.; Westerhof, N.; Marcus, J.T. Pulmonary endarterectomy normalizes interventricular dyssynchrony and right ventricular systolic wall stress. J. Cardiovasc. Magn. Reson. 2012, 14, 5. [CrossRef] [PubMed]

15. Brewis, M.J.; Bellofiore, A.; Vanderpool, R.R.; Chesler, N.C.; Johnson, M.K.; Naeije, R.; Peacock, A.J. Imaging right ventricular function to predict outcome in pulmonary arterial hypertension. Int. J. Cardiol. 2016, 218, 206-211. [CrossRef] [PubMed]

16. Marc, H.; Olivier, S.; Ari, C.; Michèle, B.; Gilbert, H.; Virginie, G.; Azzedine, Y.; Emmanuel, W.; Jean-François, C.; François, C.; et al. Survival in Patients With Idiopathic, Familial, and Anorexigen-Associated Pulmonary Arterial Hypertension in the Modern Management Era. Circulation 2010, 122, 156-163.

17. Lee, W.-T.N.; Ling, Y.; Sheares, K.K.; Pepke-Zaba, J.; Peacock, A.J.; Johnson, M.K. Predicting survival in pulmonary arterial hypertension in the UK. Eur. Respir. J. 2012, 40, 604-611. [CrossRef]

18. Benza, R.L.; Miller, D.P.; Gomberg-Maitland, M.; Frantz, R.P.; Foreman, A.J.; Coffey, C.S.; Frost, A.; Barst, R.J.; Badesch, D.B.; Elliott, C.G.; et al. Predicting survival in pulmonary arterial hypertension: Insights from the Registry to Evaluate Early and Long-Term Pulmonary Arterial Hypertension Disease Management (REVEAL). Circulation 2010, 122, 164-172. [CrossRef] [PubMed]

19. Thenappan, T.; Shah, S.J.; Rich, S.; Tian, L.; Archer, S.L.; Gomberg-Maitland, M. Survival in pulmonary arterial hypertension: A reappraisal of the NIH risk stratification equation. Eur. Respir. J. 2010, 35, 1079-1087. [CrossRef] [PubMed]

20. Van de Veerdonk, M.C.; Kind, T.; Marcus, J.T.; Mauritz, G.-J.; Heymans, M.W.; Bogaard, H.-J.; Boonstra, A.; Marques, K.M.J.; Westerhof, N.; Vonk-Noordegraaf, A. Progressive Right Ventricular Dysfunction in Patients With Pulmonary Arterial Hypertension Responding to Therapy. J. Am. Coll. Cardiol. 2011, 58, 2511-2519. [CrossRef]

21. Vanderpool, R.R.; Rischard, F.; Naeije, R.; Hunter, K.; Simon, M.A. Simple functional imaging of the right ventricle in pulmonary hypertension: Can right ventricular ejection fraction be improved? Int. J. Cardiol. 2016, 223, 93-94. [CrossRef] 
22. Dong, Y.; Pan, Z.; Wang, D.; Lv, J.; Fang, J.; Xu, R.; Ding, J.; Cui, X.; Xie, X.; Wang, X.; et al. Prognostic Value of Cardiac Magnetic Resonance-Derived Right Ventricular Remodeling Parameters in Pulmonary Hypertension. Circ. Cardiovasc. Imaging 2020, 13, e010568. [CrossRef] [PubMed]

23. Mouratoglou, S.A.; Kallifatidis, A.; Pitsiou, G.; Grosomanidis, V.; Kamperidis, V.; Chalikias, G.; Kristo, D.; Tziakas, D.; Konstantinides, S.; Hadjimiltiades, S.; et al. Duration of interventricular septal shift toward the left ventricle is associated with poor clinical outcome in precapillary pulmonary hypertension: A cardiac magnetic resonance study. Hell. J. Cardiol. HJC Hell. Kardiol. Ep. 2020, 61, 112-117. [CrossRef] [PubMed]

24. Hardegree, E.L.; Sachdev, A.; Fenstad, E.R.; Villarraga, H.R.; Frantz, R.P.; McGoon, M.D.; Oh, J.K.; Ammash, N.M.; Connolly, H.M.; Eidem, B.W.; et al. Impaired Left Ventricular Mechanics in Pulmonary Arterial Hypertension. Circ. Heart Fail. 2013, 6, 748-755. [CrossRef]

25. Kishiki, K.; Singh, A.; Narang, A.; Gomberg-Maitland, M.; Goyal, N.; Maffessanti, F.; Besser, S.A.; Mor-Avi, V.; Lang, R.M.; Addetia, K. Impact of Severe Pulmonary Arterial Hypertension on the Left Heart and Prognostic Implications. J. Am. Soc. Echocardiogr. 2019, 32, 1128-1137. [CrossRef]

26. Padervinskienė, L.; Krivickienè, A.; Hoppenot, D.; Miliauskas, S.; Basevičius, A.; Nedzelskienè, I.; Jankauskas, A.; Šimkus, P.; Ereminiene, E. Prognostic Value of Left Ventricular Function and Mechanics in Pulmonary Hypertension: A Pilot Cardiovascular Magnetic Resonance Feature Tracking Study. Medicina 2019, 55, 73. [CrossRef] [PubMed]

27. Lazar, J.M.; Flores, A.R.; Grandis, D.J.; Orie, J.E.; Schulman, D.S. Effects of chronic right ventricular pressure overload on left ventricular diastolic function. Am. J. Cardiol. 1993, 72, 1179-1182. [CrossRef]

28. Tonelli, A.R.; Plana, J.C.; Heresi, G.A.; Dweik, R.A. Prevalence and prognostic value of left ventricular diastolic dysfunction in idiopathic and heritable pulmonary arterial hypertension. Chest 2012, 141, 1457-1465. [CrossRef] [PubMed]

29. Knight, D.S.; Steeden, J.A.; Moledina, S.; Jones, A.; Coghlan, J.G.; Muthurangu, V. Left ventricular diastolic dysfunction in pulmonary hypertension predicts functional capacity and clinical worsening: A tissue phase mapping study. J. Cardiovasc. Magn. Reson. 2015, 17, 116. [CrossRef]

30. Rudski, L.G.; Lai, W.W.; Afilalo, J.; Hua, L.; Handschumacher, M.D.; Chandrasekaran, K.; Solomon, S.D.; Louie, E.K.; Schiller, N.B. Guidelines for the echocardiographic assessment of the right heart in adults: A report from the American Society of Echocardiography endorsed by the European Association of Echocardiography, a registered branch of the European Society of Cardiology, and the Canadian Society of Echocardiography. J. Am. Soc. Echocardiogr. Off. Publ. Am. Soc. Echocardiogr. 2010, 23, 685-713, quiz 786-788.

31. Lang, R.M.; Badano, L.P.; Mor-Avi, V.; Afilalo, J.; Armstrong, A.; Ernande, L.; Flachskampf, F.A.; Foster, E.; Goldstein, S.A.; Kuznetsova, T.; et al. Recommendations for cardiac chamber quantification by echocardiography in adults: An update from the American Society of Echocardiography and the European Association of Cardiovascular Imaging. J. Am. Soc. Echocardiogr. Off. Publ. Am. Soc. Echocardiogr. 2015, 28, 1-39.e14. [CrossRef]

32. Hagger, D.; Condliffe, R.; Woodhouse, N.; Elliot, C.A.; Armstrong, I.J.; Davies, C.; Hill, C.; Akil, M.; Wild, J.M.; Kiely, D.G. Ventricular mass index correlates with pulmonary artery pressure and predicts survival in suspected systemic sclerosis-associated pulmonary arterial hypertension. Rheumatol. Oxf. Engl. 2009, 48, 1137-1142. [CrossRef]

33. Vonk, M.C.; Sander, M.H.; van den Hoogen, F.H.J.; van Riel, P.L.C.M.; Verheugt, F.W.A.; van Dijk, A.P.J. Right ventricle Tei-index: A tool to increase the accuracy of non-invasive detection of pulmonary arterial hypertension in connective tissue diseases. Eur. $J$. Echocardiogr. J. Work. Group Echocardiogr. Eur. Soc. Cardiol. 2007, 8, 317-321. [CrossRef]

34. Ghio, S.; Klersy, C.; Magrini, G.; D'Armini, A.M.; Scelsi, L.; Raineri, C.; Pasotti, M.; Serio, A.; Campana, C.; Viganò, M. Prognostic relevance of the echocardiographic assessment of right ventricular function in patients with idiopathic pulmonary arterial hypertension. Int. J. Cardiol. 2010, 140, 272-278. [CrossRef] [PubMed]

35. Ghio, S.; Pazzano, A.S.; Klersy, C.; Scelsi, L.; Raineri, C.; Camporotondo, R.; D’Armini, A.; Visconti, L.O. Clinical and prognostic relevance of echocardiographic evaluation of right ventricular geometry in patients with idiopathic pulmonary arterial hypertension. Am. J. Cardiol. 2011, 107, 628-632. [CrossRef]

36. Sachdev, A.; Villarraga, H.R.; Frantz, R.P.; McGoon, M.D.; Hsiao, J.-F.; Maalouf, J.F.; Ammash, N.M.; McCully, R.B.; Miller, F.A.; Pellikka, P.A.; et al. Right ventricular strain for prediction of survival in patients with pulmonary arterial hypertension. Chest 2011, 139, 1299-1309. [CrossRef] [PubMed]

37. Forfia, P.R.; Fisher, M.R.; Mathai, S.C.; Housten-Harris, T.; Hemnes, A.R.; Borlaug, B.A.; Chamera, E.; Corretti, M.C.; Champion, H.C.; Abraham, T.P.; et al. Tricuspid annular displacement predicts survival in pulmonary hypertension. Am. J. Respir. Crit. Care Med. 2006, 174, 1034-1041. [CrossRef] [PubMed]

38. Grapsa, J.; Nunes, M.C.P.; Tan, T.C.; Cabrita, I.Z.; Coulter, T.; Smith, B.C.F.; Dawson, D.; Gibbs, J.S.R.; Nihoyannopoulos, P. Echocardiographic and Hemodynamic Predictors of Survival in Precapillary Pulmonary Hypertension. Circ. Cardiovasc. Imaging 2015, 8, e002107. [CrossRef] [PubMed]

39. Moriyama, H.; Murata, M.; Kataoka, M.; Kawakami, T.; Endo, J.; Kohno, T.; Itabashi, Y.; Seo, Y.; Iwao, Y.; Fukuda, K. Right Ventricle-Specific Three-Dimensional Wall Motion Tracking for Visualization of Regional Wall Motion Abnormality in Patients With Pulmonary Arterial Hypertension. Circ. Cardiovasc. Imaging 2019, 12, e008795. [CrossRef]

40. Anavekar, N.S.; Gerson, D.; Skali, H.; Kwong, R.Y.; Yucel, E.K.; Solomon, S.D. Two-dimensional assessment of right ventricular function: An echocardiographic-MRI correlative study. Echocardiography (Mt. Kisco N.Y.) 2007, 24, 452-456. [CrossRef] 
41. Tei, C.; Dujardin, K.S.; Hodge, D.O.; Bailey, K.R.; McGoon, M.D.; Tajik, A.J.; Seward, J.B. Doppler echocardiographic index for assessment of global right ventricular function. J. Am. Soc. Echocardiogr. 1996, 9, 838-847. [CrossRef]

42. Cabrita, I.Z.; Ruisanchez, C.; Dawson, D.; Grapsa, J.; North, B.; Howard, L.S.; Pinto, F.J.; Nihoyannopoulos, P.; Gibbs, J.S.R. Right ventricular function in patients with pulmonary hypertension; the value of myocardial performance index measured by tissue Doppler imaging. Eur. J. Echocardiogr. J. Work. Group Echocardiogr. Eur. Soc. Cardiol. 2010, 11, 719-724. [CrossRef]

43. Sato, T.; Tsujino, I.; Ohira, H.; Oyama-Manabe, N.; Yamada, A.; Ito, Y.M.; Goto, C.; Watanabe, T.; Sakaue, S.; Nishimura, M. Validation study on the accuracy of echocardiographic measurements of right ventricular systolic function in pulmonary hypertension. J. Am. Soc. Echocardiogr. Off. Publ. Am. Soc. Echocardiogr. 2012, 25, 280-286. [CrossRef] [PubMed]

44. Lindqvist, P.; Waldenström, A.; Henein, M.; Mörner, S.; Kazzam, E. Regional and global right ventricular function in healthy individuals aged 20-90 years: A pulsed Doppler tissue imaging study: Umeå General Population Heart Study. Echocardiography (Mt. Kisco N.Y.) 2005, 22, 305-314. [CrossRef] [PubMed]

45. Ernande, L.; Cottin, V.; Leroux, P.-Y.; Girerd, N.; Huez, S.; Mulliez, A.; Bergerot, C.; Ovize, M.; Mornex, J.-F.; Cordier, J.-F.; et al. Right Isovolumic Contraction Velocity Predicts Survival in Pulmonary Hypertension. J. Am. Soc. Echocardiogr. 2013, 26, 297-306. [CrossRef] [PubMed]

46. Guazzi, M.; Naeije, R.; Arena, R.; Corrà, U.; Ghio, S.; Forfia, P.; Rossi, A.; Cahalin, L.P.; Bandera, F.; Temporelli, P. Echocardiography of Right Ventriculoarterial Coupling Combined with Cardiopulmonary Exercise Testing to Predict Outcome in Heart Failure. Chest 2015, 148, 226-234. [CrossRef] [PubMed]

47. Tello, K.; Axmann, J.; Ghofrani, H.A.; Naeije, R.; Narcin, N.; Rieth, A.; Seeger, W.; Gall, H.; Richter, M.J. Relevance of the TAPSE/PASP ratio in pulmonary arterial hypertension. Int. J. Cardiol. 2018, 266, 229-235. [CrossRef]

48. Tello, K.; Wan, J.; Dalmer, A.; Vanderpool, R.; Ghofrani, H.A.; Naeije, R.; Roller, F.; Mohajerani, E.; Seeger, W.; Herberg, U.; et al. Validation of the Tricuspid Annular Plane Systolic Excursion/Systolic Pulmonary Artery Pressure Ratio for the Assessment of Right Ventricular-Arterial Coupling in Severe Pulmonary Hypertension. Circ. Cardiovasc. Imaging 2019, 12, e009047. [CrossRef]

49. Prins, K.W.; Weir, E.K.; Archer, S.L.; Markowitz, J.; Rose, L.; Pritzker, M.; Madlon-Kay, R.; Thenappan, T. Pulmonary Pulse Wave Transit Time is Associated with Right Ventricular-Pulmonary Artery Coupling in Pulmonary Arterial Hypertension. Pulm. Circ. 2016, 6, 576-585. [CrossRef]

50. French, S.; Amsallem, M.; Ouazani, N.; Li, S.; Kudelko, K.; Zamanian, R.T.; Haddad, F.; Chung, L. Non-invasive right ventricular load adaptability indices in patients with scleroderma-associated pulmonary arterial hypertension. Pulm. Circ. 2018, 8, 2045894018788268. [CrossRef]

51. Boulate, D.; Amsallem, M.; Kuznetsova, T.; Zamanian, R.T.; Fadel, E.; Mercier, O.; Haddad, F. Echocardiographic evaluations of right ventriculo-arterial coupling in experimental and clinical pulmonary hypertension. Physiol. Rep. 2019, 7, e14322. [CrossRef] [PubMed]

52. Levy, P.T.; El Khuffash, A.; Woo, K.V.; Singh, G.K. Right Ventricular-Pulmonary Vascular Interactions: An Emerging Role for Pulmonary Artery Acceleration Time by Echocardiography in Adults and Children. J. Am. Soc. Echocardiogr. Off. Publ. Am. Soc. Echocardiogr. 2018, 31, 962-964. [CrossRef]

53. Longobardo, L.; Suma, V.; Jain, R.; Carerj, S.; Zito, C.; Zwicke, D.L.; Khandheria, B.K. Role of Two-Dimensional Speckle-Tracking Echocardiography Strain in the Assessment of Right Ventricular Systolic Function and Comparison with Conventional Parameters. J. Am. Soc. Echocardiogr. 2017, 30, 937-946.e6. [CrossRef]

54. Li, Y.; Wang, T.; Haines, P.; Li, M.; Wu, W.; Liu, M.; Chen, Y.; Jin, Q.; Xie, Y.; Wang, J.; et al. Prognostic Value of Right Ventricular Two-Dimensional and Three-Dimensional Speckle-Tracking Strain in Pulmonary Arterial Hypertension: Superiority of Longitudinal Strain over Circumferential and Radial Strain. J. Am. Soc. Echocardiogr. 2020, 33, 985-994.e1. [CrossRef]

55. Vitarelli, A.; Mangieri, E.; Terzano, C.; Gaudio, C.; Salsano, F.; Rosato, E.; Capotosto, L.; D’Orazio, S.; Azzano, A.; Truscelli, G.; et al. Three-Dimensional Echocardiography and 2D-3D Speckle-Tracking Imaging in Chronic Pulmonary Hypertension: Diagnostic Accuracy in Detecting Hemodynamic Signs of Right Ventricular (RV) Failure. J. Am. Heart Assoc. 2015, 4, e001584. [CrossRef]

56. Fine, N.M.; Chen, L.; Bastiansen, P.M.; Frantz, R.P.; Pellikka, P.A.; Oh, J.K.; Kane, G.C. Outcome Prediction by Quantitative Right Ventricular Function Assessment in 575 Subjects Evaluated for Pulmonary Hypertension. Circ. Cardiovasc. Imaging 2013, 6, 711-721. [CrossRef]

57. Mukherjee, M.; Mercurio, V.; Tedford, R.J.; Shah, A.A.; Hsu, S.; Mullin, C.J.; Sato, T.; Damico, R.; Kolb, T.M.; Mathai, S.C.; et al. Right ventricular longitudinal strain is diminished in systemic sclerosis compared with idiopathic pulmonary arterial hypertension. Eur. Respir. J. 2017, 50, 1701436. [CrossRef]

58. Hulshof, H.G.; Eijsvogels, T.M.H.; Kleinnibbelink, G.; van Dijk, A.P.; George, K.P.; Oxborough, D.L.; Thijssen, D.H.J. Prognostic value of right ventricular longitudinal strain in patients with pulmonary hypertension: A systematic review and meta-analysis. Eur. Heart J. Cardiovasc. Imaging 2019, 20, 475-484. [CrossRef]

59. Badagliacca, R.; Pezzuto, B.; Papa, S.; Poscia, R.; Manzi, G.; Pascaretta, A.; Miotti, C.; Luongo, F.; Scoccia, G.; Ciciarello, F.; et al. Right Ventricular Strain Curve Morphology and Outcome in Idiopathic Pulmonary Arterial Hypertension. JACC Cardiovasc. Imaging 2021, 14, 162-172. [CrossRef] [PubMed]

60. Badagliacca, R.; Poscia, R.; Pezzuto, B.; Papa, S.; Gambardella, C.; Francone, M.; Mezzapesa, M.; Nocioni, M.; Nona, A.; Rosati, R.; et al. Right ventricular dyssynchrony in idiopathic pulmonary arterial hypertension: Determinants and impact on pump function. J. Heart Lung Transplant. 2015, 34, 381-389. [CrossRef] [PubMed] 
61. Lamia, B.; Muir, J.-F.; Molano, L.-C.; Viacroze, C.; Benichou, J.; Bonnet, P.; Quieffin, J.; Cuvelier, A.; Naeije, R. Altered synchrony of right ventricular contraction in borderline pulmonary hypertension. Int. J. Cardiovasc. Imaging 2017, 33, 1331-1339. [CrossRef]

62. Badagliacca, R.; Reali, M.; Poscia, R.; Pezzuto, B.; Papa, S.; Mezzapesa, M.; Nocioni, M.; Valli, G.; Giannetta, E.; Sciomer, S.; et al. Right Intraventricular Dyssynchrony in Idiopathic, Heritable, and Anorexigen-Induced Pulmonary Arterial Hypertension: Clinical Impact and Reversibility. JACC Cardiovasc. Imaging 2015, 8, 642-652. [CrossRef] [PubMed]

63. Badagliacca, R.; Papa, S.; Valli, G.; Pezzuto, B.; Poscia, R.; Reali, M.; Manzi, G.; Giannetta, E.; Berardi, D.; Sciomer, S.; et al. Right ventricular dyssynchrony and exercise capacity in idiopathic pulmonary arterial hypertension. Eur. Respir. J. 2017, 49. [CrossRef] [PubMed]

64. Grapsa, J.; O’Regan, D.P.; Pavlopoulos, H.; Durighel, G.; Dawson, D.; Nihoyannopoulos, P. Right ventricular remodelling in pulmonary arterial hypertension with three-dimensional echocardiography: Comparison with cardiac magnetic resonance imaging. Eur. J. Echocardiogr. 2010, 11, 64-73. [CrossRef] [PubMed]

65. Leibundgut, G.; Rohner, A.; Grize, L.; Bernheim, A.; Kessel-Schaefer, A.; Bremerich, J.; Zellweger, M.; Buser, P.; Handke, M. Dynamic Assessment of Right Ventricular Volumes and Function by Real-Time Three-Dimensional Echocardiography: A Comparison Study With Magnetic Resonance Imaging in 100 Adult Patients. J. Am. Soc. Echocardiogr. 2010, 23, 116-126. [CrossRef] [PubMed]

66. Maffessanti, F.; Muraru, D.; Esposito, R.; Gripari, P.; Ermacora, D.; Santoro, C.; Tamborini, G.; Galderisi, M.; Pepi, M.; Badano, L.P. Age-, body size-, and sex-specific reference values for right ventricular volumes and ejection fraction by three-dimensional echocardiography: A multicenter echocardiographic study in 507 healthy volunteers. Circ. Cardiovasc. Imaging 2013, 6, 700-710. [CrossRef] [PubMed]

67. Grapsa, J.; Gibbs, J.S.R.; Dawson, D.; Watson, G.; Patni, R.; Athanasiou, T.; Punjabi, P.P.; Howard, L.S.G.E.; Nihoyannopoulos, P. Morphologic and Functional Remodeling of the Right Ventricle in Pulmonary Hypertension by Real Time Three Dimensional Echocardiography. Am. J. Cardiol. 2012, 109, 906-913. [CrossRef]

68. Sukmawan, R.; Watanabe, N.; Ogasawara, Y.; Yamaura, Y.; Yamamoto, K.; Wada, N.; Kume, T.; Okura, H.; Yoshida, K. Geometric Changes of Tricuspid Valve Tenting in Tricuspid Regurgitation Secondary to Pulmonary Hypertension Quantified by Novel System with Transthoracic Real-time 3-Dimensional Echocardiography. J. Am. Soc. Echocardiogr. 2007, 20, 470-476. [CrossRef]

69. Grapsa, J.; Gibbs, J.S.R.; Cabrita, I.Z.; Watson, G.F.; Pavlopoulos, H.; Dawson, D.; Gin-Sing, W.; Howard, L.S.G.E.; Nihoyannopoulos, P. The association of clinical outcome with right atrial and ventricular remodelling in patients with pulmonary arterial hypertension: Study with real-time three-dimensional echocardiography. Eur. Heart J. Cardiovasc. Imaging 2012, 13, 666-672. [CrossRef]

70. Jone, P.-N.; Khoo, N. Innovation in 3D Echocardiographic Imaging. Curr. Treat. Options Cardiovasc. Med. 2018, 20, 1. [CrossRef]

71. Nakaya, T.; Tsujino, I.; Nakamura, J.; Chiba, Y.; Iwano, H. Right ventricular pressure-volume loop produced with simultaneous application of three-dimensional echocardiography and high-fidelity micromanometry in a patient with pulmonary arterial hypertension. Echocardiography 2021, 38, 805-807. [CrossRef]

72. Galiè, N.; Channick, R.N.; Frantz, R.P.; Grünig, E.; Jing, Z.C.; Moiseeva, O.; Preston, I.R.; Pulido, T.; Safdar, Z.; Tamura, Y.; et al. Risk stratification and medical therapy of pulmonary arterial hypertension. Eur. Respir. J. 2019, 53. [CrossRef]

73. Mouratoglou, S.A.; Bayoumy, A.A.; Noordegraaf, A.V. Prediction Models and Scores in Pulmonary Hypertension: A Systematic Review. Curr. Pharm. Des. 2020, 27, 1266-1276. [CrossRef] [PubMed]

74. Kylhammar, D.; Kjellström, B.; Hjalmarsson, C.; Jansson, K.; Nisell, M.; Söderberg, S.; Wikström, G.; Rådegran, G. A comprehensive risk stratification at early follow-up determines prognosis in pulmonary arterial hypertension. Eur. Heart J. 2018, 39, 4175-4181. [CrossRef] [PubMed]

75. Hoeper, M.M.; Kramer, T.; Pan, Z.; Eichstaedt, C.A.; Spiesshoefer, J.; Benjamin, N.; Olsson, K.M.; Meyer, K.; Vizza, C.D.; VonkNoordegraaf, A.; et al. Mortality in pulmonary arterial hypertension: Prediction by the 2015 European pulmonary hypertension guidelines risk stratification model. Eur. Respir. J. 2017, 50, 1700740. [CrossRef] [PubMed]

76. Boucly, A.; Weatherald, J.; Savale, L.; Jaïs, X.; Cottin, V.; Prevot, G.; Picard, F.; de Groote, P.; Jevnikar, M.; Bergot, E.; et al. Risk assessment, prognosis and guideline implementation in pulmonary arterial hypertension. Eur. Respir. J. 2017, 50, 1700889. [CrossRef]

77. Benza, R.L.; Gomberg-Maitland, M.; Elliott, C.G.; Farber, H.W.; Foreman, A.J.; Frost, A.E.; McGoon, M.D.; Pasta, D.J.; Selej, M.; Burger, C.D.; et al. Predicting Survival in Patients With Pulmonary Arterial Hypertension: The REVEAL Risk Score Calculator 2.0 and Comparison With ESC/ERS-Based Risk Assessment Strategies. Chest 2019, 156, 323-337. [CrossRef]

78. Hinderliter, A.L.; Willis, P.W.; Barst, R.J.; Rich, S.; Rubin, L.J.; Badesch, D.B.; Groves, B.M.; McGoon, M.D.; Tapson, V.F.; Bourge, R.C.; et al. Effects of long-term infusion of prostacyclin (epoprostenol) on echocardiographic measures of right ventricular structure and function in primary pulmonary hypertension. Primary Pulmonary Hypertension Study Group. Circulation 1997, 95, 1479-1486. [CrossRef]

79. Raymond, R.J.; Hinderliter, A.L.; Willis, P.W.; Ralph, D.; Caldwell, E.J.; Williams, W.; Ettinger, N.A.; Hill, N.S.; Summer, W.R.; de Boisblanc, B.; et al. Echocardiographic predictors of adverse outcomes in primary pulmonary hypertension. J. Am. Coll. Cardiol. 2002, 39, 1214-1219. [CrossRef]

80. Hinderliter, A.L.; Willis, P.W.; Long, W.; Clarke, W.R.; Ralph, D.; Caldwell, E.J.; Williams, W.; Ettinger, N.A.; Hill, N.S.; Summer, W.R.; et al. Frequency and prognostic significance of pericardial effusion in primary pulmonary hypertension. PPH Study Group. Primary pulmonary hypertension. Am. J. Cardiol. 1999, 84, 481-484, A10. [CrossRef] 
81. Liu, K.; Zhang, C.; Chen, B.; Li, M.; Zhang, P. Association between right atrial area measured by echocardiography and prognosis among pulmonary arterial hypertension: A systematic review and meta-analysis. BMJ Open 2020, 10, e031316. [CrossRef] [PubMed]

82. Mouratoglou, S.A.; Dimopoulos, K.; Kamperidis, V.; Feloukidis, C.; Kallifatidis, A.; Pitsiou, G.; Stanopoulos, I.; Grosomanidis, V.; Hadjimiltiades, S.; Karvounis, H.; et al. Right Atrial Function Predicts Clinical Outcome in Patients with Precapillary Pulmonary Hypertension. J. Am. Soc. Echocardiogr. 2018, 31, 1137-1145. [CrossRef] [PubMed]

83. Hasselberg, N.E.; Kagiyama, N.; Soyama, Y.; Sugahara, M.; Goda, A.; Ryo-Koriyama, K.; Batel, O.; Chakinala, M.; Simon, M.A.; Gorcsan, J. The Prognostic Value of Right Atrial Strain Imaging in Patients with Pre-Capillary Pulmonary Hypertension. J. Am. Soc. Echocardiogr. 2021. [CrossRef]

84. Miotti, C.; Papa, S.; Manzi, G.; Scoccia, G.; Luongo, F.; Toto, F.; Malerba, C.; Cedrone, N.; Sciomer, S.; Ciciarello, F.; et al. The Growing Role of Echocardiography in Pulmonary Arterial Hypertension Risk Stratification: The Missing Piece. J. Clin. Med. 2021, 10, 619. [CrossRef] [PubMed]

85. Galiè, N.; Manes, A.; Negro, L.; Palazzini, M.; Bacchi-Reggiani, M.L.; Branzi, A. A meta-analysis of randomized controlled trials in pulmonary arterial hypertension. Eur. Heart J. 2009, 30, 394-403. [CrossRef]

86. Wang, S.; Yu, M.; Zheng, X.; Dong, S. A Bayesian network meta-analysis on the efficacy and safety of eighteen targeted drugs or drug combinations for pulmonary arterial hypertension. Drug Deliv. 2018, 25, 1898-1909. [CrossRef]

87. Gaine, S.; McLaughlin, V. Pulmonary arterial hypertension: Tailoring treatment to risk in the current era. Eur. Respir. Rev. Off. J. Eur. Respir. Soc. 2017, 26, 170095. [CrossRef]

88. Peacock, A.J.; Crawley, S.; McLure, L.; Blyth, K.G.; Vizza, C.D.; Poscia, R.; Francone, M.; Iacucci, I.; Olschewski, H.; Kovacs, G.; et al. Changes in right ventricular function measured by cardiac magnetic resonance imaging in patients receiving pulmonary arterial hypertension-targeted therapy: The EURO-MR study. Circ. Cardiovasc. Imaging 2014, 7, 107-114. [CrossRef]

89. D'Alto, M.; Badagliacca, R.; Argiento, P.; Romeo, E.; Farro, A.; Papa, S.; Sarubbi, B.; Russo, M.G.; Vizza, C.D.; Golino, P.; et al. Risk Reduction and Right Heart Reverse Remodeling by Upfront Triple Combination Therapy in Pulmonary Arterial Hypertension. Chest 2020, 157, 376-383. [CrossRef] [PubMed]

90. Saggar, R.; Khanna, D.; Vaidya, A.; Derhovanessian, A.; Maranian, P.; Duffy, E.; Belperio, J.A.; Weigt, S.S.; Dua, S.; Shapiro, S.S.; et al. Changes in right heart haemodynamics and echocardiographic function in an advanced phenotype of pulmonary hypertension and right heart dysfunction associated with pulmonary fibrosis. Thorax 2014, 69, 123-129. [CrossRef] [PubMed]

91. Mercurio, V.; Mukherjee, M.; Tedford, R.J.; Zamanian, R.T.; Khair, R.M.; Sato, T.; Minai, O.A.; Torres, F.; Girgis, R.E.; Chin, K.; et al. Improvement in Right Ventricular Strain with Ambrisentan and Tadalafil Upfront Therapy in Scleroderma-associated Pulmonary Arterial Hypertension. Am. J. Respir. Crit. Care Med. 2018, 197, 388-391. [CrossRef] [PubMed]

92. Taran, I.N.; Belevskaya, A.A.; Saidova, M.A.; Martynyuk, T.V.; Chazova, I.E. Initial Riociguat Monotherapy and Transition from Sildenafil to Riociguat in Patients with Idiopathic Pulmonary Arterial Hypertension: Influence on Right Heart Remodeling and Right Ventricular-Pulmonary Arterial Coupling. Lung 2018, 196, 745-753. [CrossRef] [PubMed]

93. Tonelli, A.R.; Conci, D.; Tamarappoo, B.; Newman, J.; Dweik, R.A. Prognostic value of echocardiographic changes in patients with pulmonary arterial hypertension receiving parenteral prostacyclin therapy. J. Am. Soc. Echocardiogr. Off. Publ. Am. Soc. Echocardiogr. 2014, 27, 733-741.e2. [CrossRef]

94. Nath, J.; Demarco, T.; Hourigan, L.; Heidenreich, P.A.; Foster, E. Correlation between right ventricular indices and clinical improvement in epoprostenol treated pulmonary hypertension patients. Echocardiography (Mt. Kisco N.Y.) 2005, 22, 374-379. [CrossRef]

95. Kaya, M.G.; Lam, Y.-Y.; Erer, B.; Ayhan, S.; Vatankulu, M.A.; Nurkalem, Z.; Meric, M.; Eren, M.; Eryol, N.K. Long-term effect of bosentan therapy on cardiac function and symptomatic benefits in adult patients with Eisenmenger syndrome. J. Card. Fail. 2012, 18, 379-384. [CrossRef]

96. Kim, H.; Lee, J.B.; Park, J.-H.; Yoo, B.-S.; Son, J.-W.; Yang, D.H.; Lee, B.-R. A comparison of echocardiographic variables of right ventricular function with exercise capacity after bosentan treatment in patients with pulmonary arterial hypertension: Results from a multicenter, prospective, cohort study. J. Clin. Ultrasound 2017, 45, 28-34. [CrossRef]

97. Borges, A.C.; Knebel, F.; Eddicks, S.; Panda, A.; Schattke, S.; Witt, C.; Baumann, G. Right Ventricular Function Assessed by Two-Dimensional Strain and Tissue Doppler Echocardiography in Patients With Pulmonary Arterial Hypertension and Effect of Vasodilator Therapy. Am. J. Cardiol. 2006, 98, 530-534. [CrossRef]

98. Galiè, N.; Hinderliter, A.L.; Torbicki, A.; Fourme, T.; Simonneau, G.; Pulido, T.; Espinola-Zavaleta, N.; Rocchi, G.; Manes, A.; Frantz, R.; et al. Effects of the oral endothelin-receptor antagonist bosentan on echocardiographic and doppler measures in patients with pulmonary arterial hypertension. J. Am. Coll. Cardiol. 2003, 41, 1380-1386. [CrossRef]

99. Ruiz, M.J.; Escribano, P.; Delgado, J.F.; Jiménez, C.; Tello, R.; Gómez, M.A.; de la Calzada, C.S. Efficacy of sildenafil as a rescue therapy for patients with severe pulmonary arterial hypertension and given long-term treatment with prostanoids: 2-year experience. J. Heart Lung Transplant. Off. Publ. Int. Soc. Heart Transplant. 2006, 25, 1353-1357. [CrossRef]

100. López-Guarch, C.J.; Subias, P.E.; de Meneses, R.T.; Jiménez, J.F.D.; Pérez, D.S.; Martín, M.T.V.; Sánchez, M.A.G.; de la Calzada, C.S. Efficacy of oral sildenafil as rescue therapy in patients with severe pulmonary arterial hypertension chronically treated with prostacyclin. Long-term results. Rev. Esp. Cardiol. 2004, 57, 946-951. [CrossRef] 
101. Shah, A.M.; Campbell, P.; Rocha, G.Q.; Peacock, A.; Barst, R.J.; Quinn, D.; Solomon, S.D.; IMPRES Investigators. Effect of imatinib as add-on therapy on echocardiographic measures of right ventricular function in patients with significant pulmonary arterial hypertension. Eur. Heart J. 2015, 36, 623-632. [CrossRef] [PubMed]

102. Giusca, S.; Jurcut, R.; Coman, I.M.; Ghiorghiu, I.; Catrina, D.; Popescu, B.A.; Dima, L.; Ginghina, C. Right ventricular function predicts clinical response to specific vasodilator therapy in patients with pulmonary hypertension. Echocardiography (Mt. Kisco N.Y.) 2013, 30, 17-26. [CrossRef] [PubMed]

103. Hsu, H.-H.; Chen, J.-S.; Chen, R.J.; Ko, W.-J.; Kuo, S.-W.; Wu, E.-T.; Wu, M.-H.; Wang, J.-K.; Lee, Y.-C. Long-term outcome and effects of oral bosentan therapy in Taiwanese patients with advanced idiopathic pulmonary arterial hypertension. Respir. Med. 2007, 101, 1556-1562. [CrossRef] [PubMed]

104. Hassoun, P.M.; Zamanian, R.T.; Damico, R.; Lechtzin, N.; Khair, R.; Kolb, T.M.; Tedford, R.J.; Hulme, O.L.; Housten, T.; Pisanello, C.; et al. Ambrisentan and Tadalafil Up-front Combination Therapy in Scleroderma-associated Pulmonary Arterial Hypertension. Am. J. Respir. Crit. Care Med. 2015, 192, 1102-1110. [CrossRef]

105. Agapito, A.F.; Sousa, L.; Oliveira, J.A.; Feliciano, J.; Cacela, D.; Quininha, J. Eisenmenger syndrome in the adult-Experience with new drugs for the treatment of pulmonary hypertension. Rev. Port. Cardiol. Orgao Of. Soc. Port. Cardiol. Port. J. Cardiol. Off. J. Port. Soc. Cardiol. 2005, 24, 421-431.

106. Taçoy, G.; Başer, H.D.; Türkoğlu, S.; Cengel, A. The management of adult female patients with Eisenmenger syndrome and advanced pulmonary arterial hypertension treatment: Single center experience and follow-up for 5 years. Turk Kardiyol. Dernegi Arsivi Turk Kardiyol. Derneginin Yayin Organidir 2014, 42, 531-541. [CrossRef] [PubMed]

107. Hansmann, G.; Meinel, K.; Bukova, M.; Chouvarine, P.; Wåhlander, H.; Koestenberger, M.; European Pediatric Pulmonary Vascular Disease Network (EPPVDN). Selexipag for the treatment of children with pulmonary arterial hypertension: First multicenter experience in drug safety and efficacy. J. Heart Lung Transplant. Off. Publ. Int. Soc. Heart Transplant. 2020, 39, 695-706. [CrossRef]

108. Badagliacca, R.; Raina, A.; Ghio, S.; D’Alto, M.; Confalonieri, M.; Correale, M.; Corda, M.; Paciocco, G.; Lombardi, C.; Mulè, M.; et al. Influence of various therapeutic strategies on right ventricular morphology, function and hemodynamics in pulmonary arterial hypertension. J. Heart Lung Transplant. Off. Publ. Int. Soc. Heart Transplant. 2018, 37, 365-375. [CrossRef]

109. Gabrielli, L.; Ocaranza, M.P.; Sitges, M.; Kanacri, A.; Saavedra, R.; Sepulveda, P.; Sepulveda, L.; Rossel, V.; Zagolin, M.; Verdejo, H.E.; et al. Acute effect of iloprost inhalation on right atrial function and ventricular dyssynchrony in patients with pulmonary artery hypertension. Echocardiography (Mt. Kisco N.Y.) 2017, 34, 53-60. [CrossRef]

110. Cha, K.S.; Cho, K.I.; Seo, J.S.; Choi, J.H.; Park, Y.H.; Yang, D.H.; Hong, G.R.; Kim, D.S. Effects of inhaled iloprost on exercise capacity, quality of life, and cardiac function in patients with pulmonary arterial hypertension secondary to congenital heart disease (the Eisenmenger syndrome) (from the EIGER Study). Am. J. Cardiol. 2013, 112, 1834-1839. [CrossRef]

111. Marra, A.M.; Halank, M.; Benjamin, N.; Bossone, E.; Cittadini, A.; Eichstaedt, C.A.; Egenlauf, B.; Harutyunova, S.; Fischer, C.; Gall, H.; et al. Right ventricular size and function under riociguat in pulmonary arterial hypertension and chronic thromboembolic pulmonary hypertension (the RIVER study). Respir. Res. 2018, 19, 258. [CrossRef] [PubMed]

112. Hardegree, E.L.; Sachdev, A.; Villarraga, H.R.; Frantz, R.P.; McGoon, M.D.; Kushwaha, S.S.; Hsiao, J.-F.; McCully, R.B.; Oh, J.K.; Pellikka, P.A.; et al. Role of serial quantitative assessment of right ventricular function by strain in pulmonary arterial hypertension. Am. J. Cardiol. 2013, 111, 143-148. [CrossRef] [PubMed]

113. Mazurek, J.A.; Vaidya, A.; Mathai, S.C.; Roberts, J.D.; Forfia, P.R. Follow-up tricuspid annular plane systolic excursion predicts survival in pulmonary arterial hypertension. Pulm. Circ. 2017, 7, 361-371. [CrossRef]

114. Shelburne, N.J.; Parikh, K.S.; Chiswell, K.; Shaw, L.K.; Sivak, J.; Arges, K.; Tomfohr, J.; Velazquez, E.J.; Kisslo, J.; Samad, Z.; et al. Echocardiographic Assessment of Right Ventricular Function and Response to Therapy in Pulmonary Arterial Hypertension. Am. J. Cardiol. 2019, 124, 1298-1304. [CrossRef]

115. Sebbag, I.; Rudski, L.G.; Therrien, J.; Hirsch, A.; Langleben, D. Effect of chronic infusion of epoprostenol on echocardiographic right ventricular myocardial performance index and its relation to clinical outcome in patients with primary pulmonary hypertension. Am. J. Cardiol. 2001, 88, 1060-1063. [CrossRef]

116. Ogihara, Y.; Yamada, N.; Dohi, K.; Matsuda, A.; Tsuji, A.; Ota, S.; Ishikura, K.; Nakamura, M.; Ito, M. Utility of right ventricular Tei-index for assessing disease severity and determining response to treatment in patients with pulmonary arterial hypertension. J. Cardiol. 2014, 63, 149-153. [CrossRef] [PubMed]

117. Hoeper, M.M.; Pittrow, D.; Opitz, C.; Gibbs, J.S.R.; Rosenkranz, S.; Grünig, E.; Olsson, K.M.; Huscher, D. Risk assessment in pulmonary arterial hypertension. Eur. Respir. J. 2018, 51, 1702606. [CrossRef]

118. Van de Veerdonk, M.C.; Marcus, J.T.; Westerhof, N.; de Man, F.S.; Boonstra, A.; Heymans, M.W.; Bogaard, H.-J.; Vonk Noordegraaf, A. Signs of right ventricular deterioration in clinically stable patients with pulmonary arterial hypertension. Chest 2015, 147, 1063-1071. [CrossRef]

119. Haddad, F.; Spruijt, O.A.; Denault, A.Y.; Mercier, O.; Brunner, N.; Furman, D.; Fadel, E.; Bogaard, H.J.; Schnittger, I.; Vrtovec, B.; et al. Right Heart Score for Predicting Outcome in Idiopathic, Familial, or Drug- and Toxin-Associated Pulmonary Arterial Hypertension. JACC Cardiovasc. Imaging 2015, 8, 627-638. [CrossRef] [PubMed]

120. Amsallem, M.; Sweatt, A.J.; Aymami, M.C.; Kuznetsova, T.; Selej, M.; Lu, H.; Mercier, O.; Fadel, E.; Schnittger, I.; McConnell, M.V.; et al. Right Heart End-Systolic Remodeling Index Strongly Predicts Outcomes in Pulmonary Arterial Hypertension. Circ. Cardiovasc. Imaging 2017, 10, e005771. [CrossRef] [PubMed] 
121. Stolfo, D.; Albani, S.; Biondi, F.; Luca, A.D.; Barbati, G.; Howard, L.; Giudice, F.L.; Tsampasian, V.; Pasanisi, E.M.; Airò, E.; et al. Global Right Heart Assessment with Speckle-Tracking Imaging Improves the Risk Prediction of a Validated Scoring System in Pulmonary Arterial Hypertension. J. Am. Soc. Echocardiogr. 2020, 33, 1334-1344.e2. [CrossRef] [PubMed]

122. Ghio, S.; Mercurio, V.; Fortuni, F.; Forfia, P.R.; Gall, H.; Ghofrani, A.; Mathai, S.C.; Mazurek, J.A.; Mukherjee, M.; Richter, M.; et al. A comprehensive echocardiographic method for risk stratification in pulmonary arterial hypertension. Eur. Respir. J. 2020, 56. [CrossRef] [PubMed]

123. Zhao, Q.-H.; Gong, S.-G.; Jiang, R.; Li, C.; Chen, G.-F.; Luo, C.-J.; Qiu, H.-L.; Liu, J.-M.; Wang, L.; Zhang, R. Echocardiographic Prognosis Relevance of Attenuated Right Heart Remodeling in Idiopathic Pulmonary Arterial Hypertension. Front. Cardiovasc. Med. 2021, 8, 650848. [CrossRef] [PubMed] 